\title{
Ganciclovir attenuates the respiratory disease induced by Equid alphaherpesvirus 1 in rabbits ${ }^{1}$
}

\author{
Ana Paula G. Mortari ${ }^{2,3}$, Bruna P. Amaral ${ }^{2,3}$, Pablo S.B. De Oliveira ${ }^{2,3}$, \\ Evelyn K. Dotto ${ }^{2,3}$, Mariana M. Flores ${ }^{3,4}$, Juliana F. Cargnelutti ${ }^{5}$, Rudi Weiblen ${ }^{2,3}$ \\ and Eduardo F. Flores ${ }^{2,3 *}$ (1)
}

\begin{abstract}
Mortari A.P.G., Amaral B.P., De Oliveira P.S.B., Dotto E.K., Flores M.M., Cargnelutti J.F., Weiblen R. \& Flores E.F. 2019. Ganciclovir attenuates the respiratory disease induced by Equid alphaherpesvirus 1 in rabbits. Pesquisa Veterinária Brasileira 39(10):830-836. Setor de Virologia, Departamento de Medicina Veterinária Preventiva, Universidade Federal de Santa Maria, Av. Roraima 1000, Rua Z, Prédio 63A, Santa Maria, RS 97105-900, Brazil. E-mail: eduardofurtadoflores@gmail.com

Equid alphaherpesvirus 1 (EHV-1) is an important pathogen of horses, associated with respiratory, neurological disease and abortions. As vaccination is not always effective, anti-herpetic therapy may represent an alternative to prevent the losses caused by the infection. We herein investigated the activity of ganciclovir (GCV), an anti-herpetic human drug, in rabbits experimentally infected with EHV-1. Thirty-days-old New Zealand rabbits were allocated in three groups ( 6 animals each) and submitted to different treatments: G1 (non-infected controls), G2 (inoculated with EHV-1) - $10^{7}$ TCID $_{50}$ intranasally - IN) and G3 (inoculated IN with EHV-1 and treated with GCV - $5 \mathrm{mg} / \mathrm{kg} /$ day for 7 days) and monitored thereafter. All animals of G2 developed systemic signs (moderate to severe apathy, anorexia), ocular discharge and respiratory signs (serous to mucopurulent nasal discharge), including mild to severe respiratory distress. Viremia was detected in all rabbits of G2 for up to 11 days (mean duration $=6.5$ days). One animal died after severe respiratory distress and neurological signs (bruxism, opistotonus). In addition, these animals gained less weight than the control (G1) and GCV-treated rabbits (G3) from days 4 to $14 \mathrm{pi}(\mathrm{p}<0.05)$. The clinical score of rabbits of G2 was statistically higher than the other groups from days 3 to $6 \mathrm{pi}(\mathrm{p}<0.05)$, demonstrating a more severe disease. In contrast, G3 rabbits did not present systemic signs, presented only a mild and transient nasal secretion and gained more weight than G2 animals ( $\mathrm{p}<0.05)$. In addition, viremia was detected in only 3 rabbits and was transient (average of 2.3 days). Thus, administration of GCV to rabbits inoculated IN with EHV-1 resulted in an important attenuation of the clinical disease as demonstrated by full prevention of systemic signs, maintenance of weight gain and by drastic reduction in viremia and in the magnitude of respiratory signs. These results are promising towards further testing of GCV as a potential drug for anti-herpetic therapy in horses.
\end{abstract}

INDEX TERMS: Ganciclovir, respiratory disease, equid alphaherpesvirus 1, rabbits, herpesvirus, therapy, EHV-1, animal model.

\footnotetext{
${ }^{1}$ Received on March 26, 2019

Accepted for publication on April 7, 2019.

${ }^{2}$ Setor de Virologia, Departamento de Medicina Veterinária Preventiva, Universidade Federal de Santa Maria, Av. Roraima 1000, prédio 63A, Santa Maria, RS 97105-900, Brazil.*Corresponding author: eduardofurtadoflores@gmail.com

${ }^{3}$ Graduate Program in Veterinary Medicine, Universidade Federal de Santa Maria, Av. Roraima 1000, Santa Maria, RS 97105-900.

${ }^{4}$ Laboratório de Patologia Veterinária, Hospital Veterinário Universitário, Universidade Federal de Santa Maria, Av. Roraima 1000, Santa Maria, RS 97105-900.

${ }^{5}$ Laboratório de Bacteriologia, Departamento de Medicina Veterinária Preventiva, Universidade Federal de Santa Maria, Av. Roraima 1000, Camobi, Santa Maria, RS 97105-900.
}

RESUMO.- [0 ganciclovir atenua a doença respiratória produzida pelo alfaherpesvírus equino 1 em coelhos.] 0 alfaherpesvírus equino 1 (EHV-1) é um importante patógeno de equinos, associado com doença respiratória, neurológica e abortos. Como a vacinação nem sempre é eficaz, a terapia anti-herpética pode representar uma alternativa para prevenir as perdas causadas pela infecção. Para tal, investigou-se a atividade do ganciclovir (GCV), uma droga anti-herpética de uso humano, em coelhos infectados experimentalmente com o EHV-1. Coelhos da raça Nova Zelândia com 30 dias de idade foram alocados em três grupos ( 6 animais cada) e submetidos 
a diferentes tratamentos: G1 (controles não infectados), G2 (inoculados com o EHV-1) - $10^{7} \mathrm{TCID}_{50}$ intranasal - IN) e G3 (inoculados IN com o EHV-1 e tratados com GCV - $5 \mathrm{mg} / \mathrm{kg} / \mathrm{dia}$ por 7 dias), e monitorados posteriormente. Todos os animais do G2 desenvolveram sinais sistêmicos (apatia moderada a grave, anorexia), secreção ocular e sinais respiratórios (secreção nasal serosa a mucopurulenta), incluindo dificuldade respiratória leve a grave. Viremia foi detectada em todos os coelhos do G2 por até 11 dias (duração média = 6,5 dias). Um animal morreu após dificuldade respiratória grave e sinais neurológicos (bruxismo, opistótono). Além disso, esses animais ganharam menos peso que os coelhos controle (G1) e tratados com GCV (G3) entre os dias 4 e 14pi $(p<0,05)$. 0 escore clínico de coelhos do G2 foi estatisticamente maior que os demais grupos dos dias 3 a $6 \mathrm{pi}(\mathrm{p}<0,05)$, demonstrando uma doença mais grave. Em contraste, os coelhos do G3 não apresentaram sinais sistêmicos, apresentaram apenas secreção nasal leve e transiente e ganharam mais peso que os animais do G2 $(\mathrm{p}<0,05)$. Além disso, a viremia foi detectada em apenas 3 coelhos e foi transitória (média de 2,3 dias). Assim, a administração de GCV a coelhos inoculados com EHV-1 resultou em uma importante atenuação da doença clínica, como demonstrado pela prevenção completa de sinais sistêmicos, manutenção do ganho de peso e pela redução drástica da viremia e da magnitude dos sinais respiratórios. Estes resultados são promissores para testes adicionais com o GCV para potencial terapêutico anti-herpética em equinos.

TERMOS DE INDEXAÇÃO: Ganciclovir, doença respiratória, alfaherpesvírus equino 1, Equid alphaherpesvirus 1, coelhos, herpesvírus, terapia, EHV-1, modelo animal.

\section{INTRODUCTION}

Equid alphaherpesvirus 1(EHV-1) is an enveloped, double-stranded DNA virus belonging to the genus Varicellovirus, subfamily Alphaherpesvirinae, family Herpesviridae (ICTV 2018). EHV-1 infection is distributed worldwide and is frequently associated with respiratory disease, abortion, perinatal foal mortality and/or neurological disease (equine herpesvirus myeloencephalopathy - EHM) (Allen \& Bryans 1986, Allen \& Umphenour 2004, Lunn et al. 2009, Goodman et al. 2012, Ma et al. 2013, Pusterla \& Hussey 2014). After acute infection, EHV-1 establishes lifelong latent infections, mainly in sensory nerve ganglia but also in lymphoid cells (Welch et al. 1992, Pusterla et al. 2010). Natural reactivation of latent infection results in virus replication and transmission to susceptible animals, representing a means of virus perpetuation in nature (Patel \& Heldens 2005).

The respiratory disease associated with EHV-1 infection is especially important in young racing horses submitted to intensive training since it affects the physical performance (Gilkerson et al.1999). The reproductive losses by abortions, perinatal foal mortality and neurological disease (EHM) resulting in high mortality, in addition to the restrictions to transportation, contribute to the economic impact of EHV-1 infection (Lunn et al. 2009).

Although vaccines against EHV- 1 are available, they are not fully protective such as outbreaks of disease have been reported even in regularly vaccinated herds (Allen \& Umphenour 2004, Kydd et al. 2012). Likewise, no specific treatment is available for the disease caused by EHV-1. Then, control measures such as support therapy and animal isolation have been indicated to reduce transmission and to minimize clinical signs (Carmichael \& Greene 2006). Considering the high economic value of some horses, EHV-1 infection represents an attractive target for testing and, eventually employing antiviral drugs (Schwers et al. 1980, Maggs \& Clarke 2004, Bentz et al. 2006, Marley et al. 2006, Meulen et al. 2006, Garré et al. 2007a).

A number of drugs have been successfully used for the treatment of herpetic infections in humans, yet their use in veterinary medicine is still incipient (De Clercq 2008, Razonable 2011, Maxwell 2017). However, some studies investigated the antiviral action of drugs against bovine herpesviruses (1, 2 and 5) (Dezengrini et al. 2010), felid herpesvirus (Thomasy \& Maggs 2016) and herpesviruses of horses (Vissani et al. 2015, Oliveira et al. 2018). These drugs may have important applications in equine medicine by reducing the clinical consequences of herpetic infections (Garré et al. 2008, Carmichael et al. 2013, Glorieux et al. 2012, Maxwell et al. 2008, Maxwell 2017).

Antiviral drugs include the nucleoside analogs acyclovir (ACV), ganciclovir (GCV), cidofovir (CDV), famciclovir (FAM), foscarnet (FOS) and vidarabine (VID) (Coen \& Richman 2007). The action of these drugs occurs via their incorporation into the nascent DNA molecule, halting the DNA polymerase from completing polymerization (Whitley \& Roizman 2001, Coen \& Richman 2007, Levinson 2016). A number of studies in vitro has indicated the efficacy and safety of some of these drugs against EHV-1, especially GCV (Vissani et al. 2015, Oliveira et al. 2018), which was the most effective and safest drug among six drugs tested in vitro (Oliveira et al. 2018). Furthermore, the pharmacokinetics of GCV in horses has been already studied (Carmichael et al. 2013). The activity of GCV in horses with meningoencephalitis by EHV-1 has been demonstrated (Maxwell 2017), yet its antiviral activity in the respiratory disease induced by EHV-1 has not been investigated.

GCV was the first antiviral drug used for the treatment of cytomegalovirus (CMV) infections, and currently it is widely used in immunosuppressed patients (HIV infected, transplanted, etc.) that develop secondary CMV infection. GCV is an acyclic analog of the nucleoside guanosine, and when at triphosphate state, it is a competitive inhibitor of deoxyguanosine triphosphate incorporation into DNA and inhibits viral DNA polymerases, serving as a poor substrate for chain elongation, thereby disrupting viral DNA synthesis (Crumpacker 1996).

Thus, in this article we describe an investigation of the antiviral activity of GCV in a rabbit model for EHV-1 respiratory disease. Our results are promising towards further testing of GCV in herpetic infections of horses.

\section{MATERIALS AND METHODS}

The activity of GCV against EHV-1 in vivo was investigated in rabbits inoculated intranasally (IN) with strain Kentucky D. All procedures involving animals were performed under veterinary supervision and conducted following the guidelines by the Brazilian Committee of Animal Experimentation (COBEA, law no. 6,638, of May 8th, 1979). The animal experiment was approved by the Institutional Committee of Ethic and Animal Experimentation Welfare (UFSM - "Comitê de Ética e Experimentação Animal”: CEUA no. 3364110719).

Cells and virus. Vero cells (African Green Monkey kidney) were used in all procedures of virus amplification, quantitation, isolation 
from clinical specimens and virus-neutralizing (VN) assays. Cells were cultured in RPMI medium supplemented with $10 \%$ fetal bovine serum (Cultilab, Inc.), added of antibiotics (streptomycin $0.4 \mathrm{mg} / \mathrm{mL}$; penicillin $1.6 \mathrm{mg} / \mathrm{mL}$ ) and antifungic (anphotericin B $0.0025 \mathrm{mg} / \mathrm{mL}$ ). The EHV-1 Kentucky D strain was kindly provided by Dr Rodrigo Franco (Instituto Butantan, São Paulo/SP, Brazil).

Animals and virus inoculation. Eighteen New Zealand rabbits (approximately 30-days-old) were allocated in three groups of six animals each according to the respective treatments: G1 (uninfected controls, inoculated IN with RPMI medium); G2 (inoculated with EHV-1); G3 (inoculated with EHV-1 and treated with GCV). Animals from G2 and G3 were inoculated into the paranasal sinuses (Kanitz et al. 2015) with $1 \mathrm{~mL}$ of culture supernatant containing $10^{7}$ mean tissue culture infectious doses $\left(\right.$ TCID $_{50}$ ) of EHV-1 after sedation with ketamine $(50 \mathrm{mg} / \mathrm{kg})$ and xylazine $(5 \mathrm{mg} / \mathrm{kg})$. Starting at the day of virus inoculation, animals of G3 received GCV intravenously $(5 \mathrm{mg} / \mathrm{kg} /$ day) during seven days.

Animal monitoring and sample testing. Experimental animals were weighted and monitored in a daily basis for clinical and virological aspects up to day 15 post-inoculation (pi). Clinical monitoring involved a close observation of behavior, food ingestion, alertness, ocular and respiratory signs. A clinical score was determined per group/day by the sum of the values of the following parameters: apathy (presence: 1 , absence: 0 ); ocular secretion (presence: 1 , absence: 0 ), nasal discharge (serous: 1, mucopurulent: 2, absence: 0 ), respiratory distress (mild: 1 , mild to moderate: 2 , moderate to severe: 3 , absence: 0 ), neurological signs (presence: 1 , absence: 0 ), death (yes: 1 , no: 0 ).

Nasal swabs were collected in alternate days up to day $15 \mathrm{pi}$ and submitted to virus isolation. For virus isolation, swabs collected in $0.5 \mathrm{~mL}$ of RPMI medium were drained, centrifuged $(1,000 \mathrm{xg}$ for $10 \mathrm{~min}$ ) and the $0.1 \mathrm{~mL}$ of the supernatant was inoculated onto Vero cell monolayers grown in 24-well plates. Samples were submitted to three passages of four days each and monitored for cytopathic effect (cpe). Lung fragments collected from rabbit \#28 (G3) which died at day 3pi were also submitted to virus isolation in Vero cells.

Viremia was investigated by submitting blood collected in alternate days $(50 \mu \mathrm{l} /$ animal) to DNA extraction by phenol-chloroform and a PCR for EHV-1 gB gene according to Kanitz et al. (2015). Total DNA extracted from uninfected Vero cells and from cells inoculated with EHV-1 was used as negative and positive controls, respectively.
Blood for serology was collected at days 0 and 15pi. Serum samples were submitted to a standard microtiter virus-neutralizing (VN) assay, testing two-fold dilutions of serum against a fixed dose of virus (100-200 TCID $_{50}$ ). Vero cells were used as indicators and the readings were performed at $96 \mathrm{~h}$ of incubation. VN titers were considered the reciprocal of the highest serum dilution capable of preventing the production of cpe.

Lungs collected from rabbit \# 28 were fixed in 10\% buffered formalin, embedded in paraffin, cut at $5 \mu \mathrm{m}$ and stained with hematoxylin and eosin for microscopic examination.

Statistical analysis. The weight values and clinical score obtained daily from all experimental animals were submitted to variance analysis by the Two-way ANOVA method, with Tukey test for multiple comparisons, using the GraphPad Prism (version 6) software. Differences between the groups were considered significant when the $p$ values were lower than $5 \%(\mathrm{p}<0.05)$.

\section{RESULTS}

All six rabbits inoculated with EHV-1 (G2) developed systemic and respiratory signs from day 2 to 11 pi, shed virus in nasal secretions from day 1 to 13 pi and seroconverted to EHV-1 (VN titers from 8 to 128) (Table 1). The disease was characterized by moderate to severe apathy and anorexia, serous ocular secretion, nasal discharge (serous to muco-purulent) and mild to severe respiratory distress. Rabbit \# 28 died at day 3 pi after a course of respiratory distress, bruxism and opistothonus. Infectious virus and histological changes compatible with virus-associated inflammation were observed in the lungs of this animal. Viremia was detected in G2 animals from day 3 to 13pi (mean duration $=6.5$ days). In addition, G2 rabbits presented a reduced weight gain comparing to uninfected controls (G1) and GVC treated rabbits (G3) from day 4 to 14 pi $(\mathrm{p}<0.05)$. These results demonstrated the production of systemic and respiratory disease by EHV-1 in rabbits infected experimentally.

In contrast, no systemic signs (changes in alertness, appetite) or overt respiratory signs were observed in rabbits inoculated with EHV-1 and receiving GCV treatment (G3). The clinical score, compiling respiratory and systemic signs, was statistically higher $(\mathrm{p}<0.01)$ in G2 rabbits than in GCV treated animals (G3) from day 3 to 6pi (Fig.1), illustrating

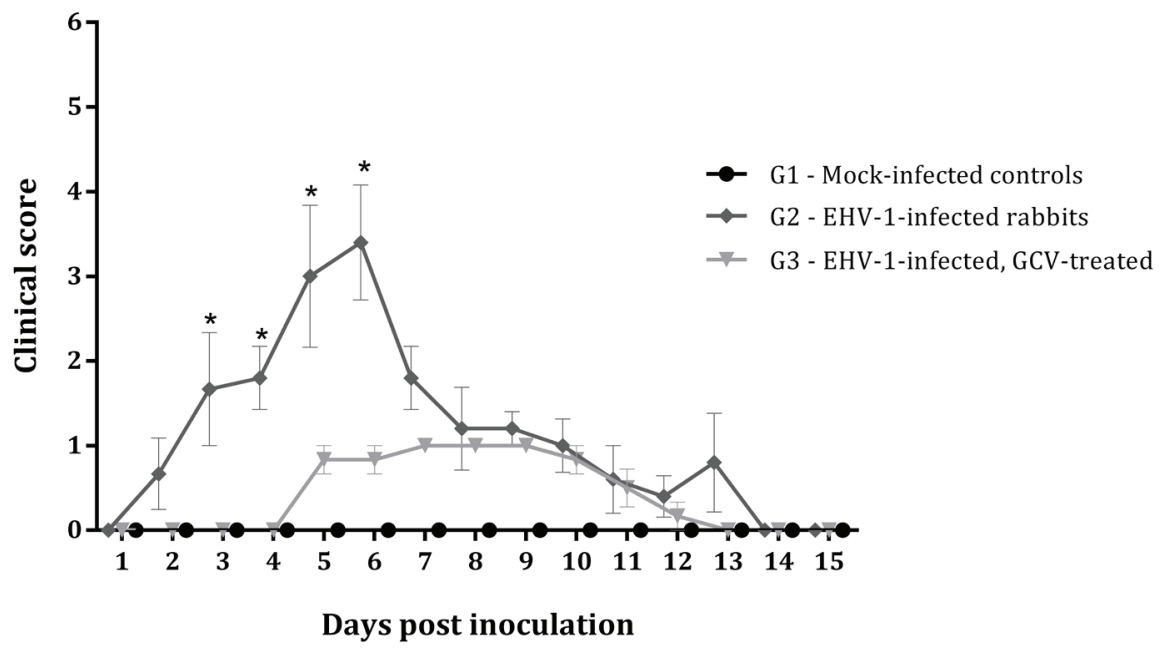

Fig.1. Mean of clinical scores obtained daily from the groups of rabbits experimentally infected with EHV-1 (G2) and infected with EHV-1 and treated with ganciclovir (G3). Statistical difference between groups G2 and G3 (*), p<0.001. 
the important reduction in the magnitude of clinical signs in animals receiving GCV (G3). These animals presented only a mild serous nasal secretion between days 5 and $12 \mathrm{pi}$. The weight gain of these animals was comparable to the uninfected control group and higher than the $\mathrm{G} 2$ group at days $4,6,10,12$ and $14(p<0.05)$ (Fig.2). G3 animals shed virus in nasal secretions from day 1 to $15 \mathrm{pi}$ and $5 / 6$ seroconverted to EHV-1 at day 15pi, harboring VN titers from 8 to 32 (Table 1).

Table 1. Clinical, virological and serological findings of equid alphaherpesvirus 1 (EHV-1) infected rabbits and treated with ganciclovir (GCV)

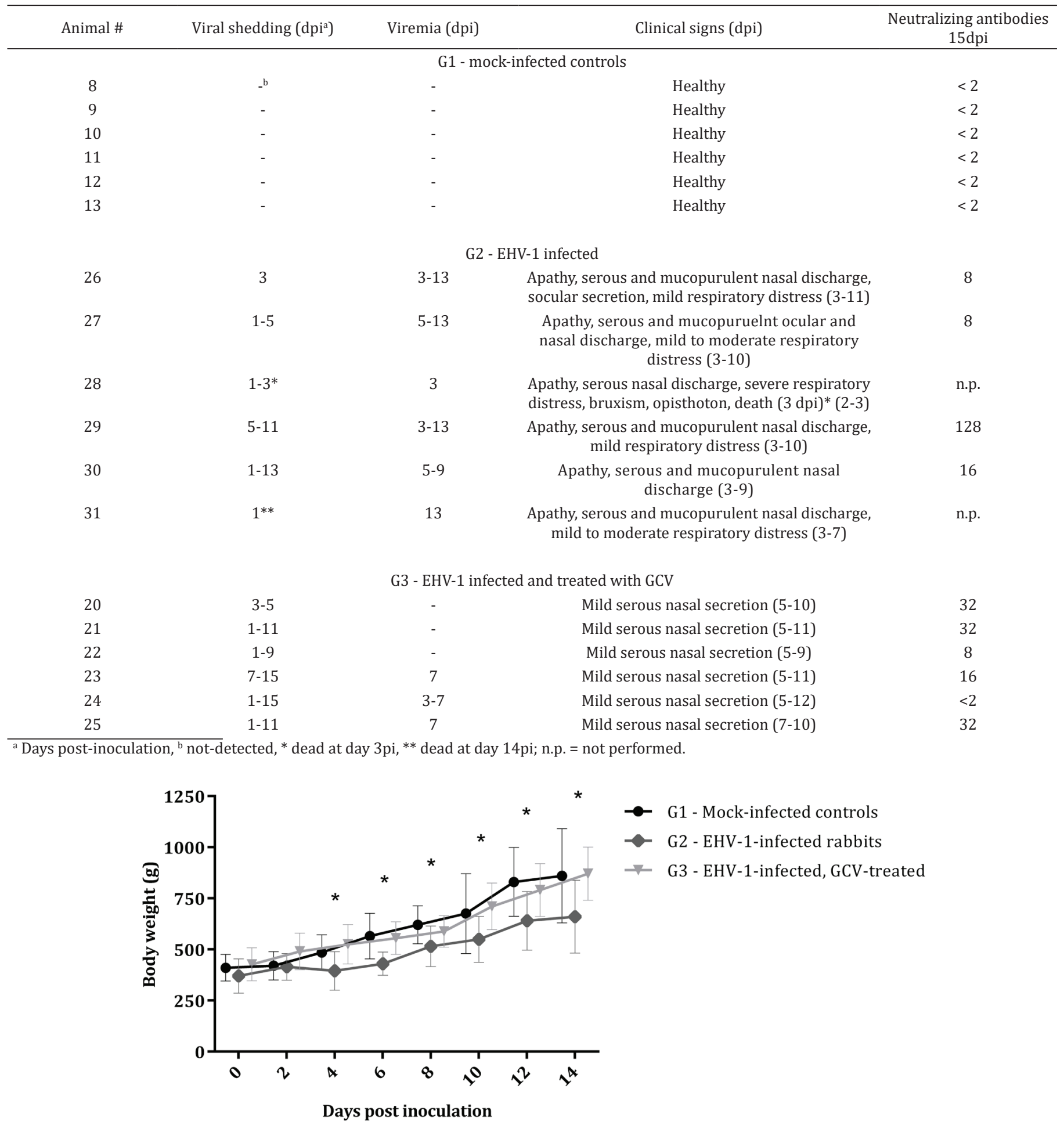

Fig.2. Mean and standard deviation of the mean of body weight of control group (G1), EHV-1 inoculated rabbits (G2) and EHV-1 inoculated rabbits and treated with ganciclovir (G3). Significant statistical difference between groups $(*), p<0.05$. No statistical differences in weight gain was between G1 and G3. 
Transient viremia was detected in only 3 rabbits and lasted an average of 2.3 days. These results demonstrate that GCV treatment fully prevented the development of systemic signs, preserved weight gain, reduced viremia and resulted in an important attenuation of the systemic and respiratory disease.

No difference in virus shedding (duration) was evident between rabbits from G2 and G3 (Table 1). Uninfected rabbits remained healthy, did not shed virus or presented viremia, gained weight and remained seronegative to EHV-1 throughout the experiment.

\section{DISCUSSION}

The administration of GCV to rabbits inoculated IN with EHV-1 resulted in an important attenuation of the clinical disease as demonstrated by full prevention of systemic signs, maintenance of weight gain and by a drastic reduction in viremia and in the magnitude of respiratory signs. As one animal from G2 (\# 28) died after severe respiratory and neurological signs, the prevention of mortality may be also attributed to GCV treatment. These results may pave the way for further studies in rabbits and, eventually in horses, to investigate the real potential of GCV as an anti-herpetic drug for equine medicine. Although antiviral treatment of animals may be expensive due to difficulties to obtain GCV in large scale, the benefits of treating horses against EHV-1 infection may be rewarding.

Anti-herpetic therapy has long been used in human medicine yet its application in veterinary medicine is still incipient. Since vaccination is not always effective in preventing respiratory, neurological disease and abortions associated with EHV-1 infections, antiviral therapy may represent an attractive alternative to reduce the losses caused by these conditions. In fact, human anti-herpetic drugs have been tested for the therapy of diseases caused by EHV-1 and other equine herpesviruses as well (reviewed by Vissani et al. 2015, Maxwell 2017). However, many evidences of anti-herpetic drug efficacy against equine herpesviruses are derived from studies in vitro or in animal models, from empirical data, with limited testing and/or clinical experience in horses (Maxwell 2017). In fact, although investigation of anti-viral therapy has been performed for several equine herpesviruses, only diseases associated with EHV-1 and EHV-5 infections have been treated with anti-herpetic drugs in routine equine practice (Vissani et al. 2015, Maxwell 2017).

Acyclovir and its prodrug, valacyclovir are the human anti-herpetic drugs more commonly tested in EHV therapy. Oral valacyclovir has been used to protect adult horses from EHV-1 myeloencephalopathy. Oral acyclovir is frequently administered for the therapy of equine multinodular pulmonary fibrosis associated with EHV-5 infection. Other anti-herpetic drugs are promising but require further investigation (reviewed by Maxwell 2017).

GCV has been the drug of choice to replace acyclovir (ACV) in the therapy of herpes simplex virus infections in humans since it is less toxic and more stable (Shen et al. 2009). The efficacy of GCV in attenuating clinical disease has been demonstrated for different human herpesviruses, including Epstein-Barr virus (Egan et al. 2011), CMV in immunodepressed patients (Lalezari et al. 2002), keratitis by HSV-1 (Wang et al. 2015) and encephalitis by HHV-6 (Mookerjee \& Vogelsang 1997).
Several studies have shown that GCV is, at least, 10 times more potent than acyclovir and penciclovir against EHV-1 in vitro and in mice (reviewed by Maxwell 2017, Oliveira et al. 2018). In addition, GCV presents a favorable pharmacokinetic profile and it is well tolerated for horses (Carmichael et al. 2013). Investigation of GCV anti-EHV-1 activity in cases of neurological disease, however, has yielded conflicting results. GCV administration to experimentally infected horses at the onset of fever was able to reduce the severity of neurological signs, viremia and temperature (Maxwell 2017). On the other hand, GCV treatment of two naturally infected horses developing mioencephalopathy was unable to reduce the severity of clinical disease and death (Estell et al. 2015). The activity of GCV against EHV-1 in vitro has been demonstrated, being a potent and selective compound (Oliveira et al. 2018). Regardless, the activity of GCV in the respiratory disease by EHV-1 remained unexploited. In this study we investigated its activity in vivo, using a rabbit model for EHV-1 respiratory disease established previously (Kanitz et al. 2015).

Treatment of rabbits inoculated with EHV-1 with GCV starting at the day of virus inoculation was effective in preventing systemic disease, in maintaining weight gain and drastically reducing viremia and the severity of respiratory signs. Interestingly, GCV treatment apparently did not interfere with virus replication in the nasal mucosa since the duration of virus shedding through nasal secretions was similar in G2 and G3 groups. It is conceivable that GCV may have interfered with virus replication in the lower respiratory tract, especially in the lungs, what would explain the prevention of systemic disease and attenuation of respiratory signs observed in treated animals (G3). Demonstration of infectious virus and inflammatory changes in the lungs of rabbit \#28, which died after severe respiratory and neurological signs, reinforce that EHV-1 pathogenesis involves replication in lower respiratory tract. Indeed, pulmonary inflammation secondary to EHV-1 infection can cause substantial morbidity and mortality in neonatal foals and upper respiratory signs in weanlings (Murray et al. 1998, Brown et al. 2007). Drastic reduction in viremia reinforces that GCV treatment, at some stage, reduced EHV-1 replication and/or systemic spread.

The therapeutic protocol, including drug dose, route and interval of administration and duration was adapted from previous studies of pharmacokinetics and toxicity in rabbits and horses (Hedaya \& Sawchuk 1990, Carmichael et al. 2013) and based on previous studies showing antiviral activity in vitro (Garré et al. 2007a, Oliveira et al. 2018). Implementing GCV administration at the day of virus inoculation, however, is rather unusual and obviously does not reflect the clinical practice. By doing so, we tried to proof the concept of GCV activity in vivo against EHV-1-induced respiratory disease. Whether GCV will be capable of attenuating clinical disease by EHV-1 when administered after the onset of clinical signs will demand further studies. In any case, our results demonstrated antiherpetic activity of GCV in vivo and are, therefore, promising towards further studies to define the real potential of GCV as a drug for therapy of herpetic infections in horses.

In any case, our results are promising towards the use of GCV in the therapy of EHV-1 disease in horses and open the way for further studies of GCV activity against EHV-1 respiratory disease in animal models and, in a second phase, in its natural host. 


\section{CONCLUSION}

Intravenous administration of GCV at a dose of $2.5 \mathrm{mg} / \mathrm{kg}$ every $12 \mathrm{~h}$ for 7 days in rabbits inoculated with EHV-1 by the intranasal route was effective in preventing systemic signs, attenuating respiratory disease, reducing viremia and preserving weight gain, when comparing with untreated rabbits. These results indicate that this drug may be a good alternative for experimental studies in horses, aiming to establish an anti-herpetic therapeutic protocol for this species.

Acknowledgments.- Thanks to Paula de Almeida Rodrigues, Ananda Segabinazzi Ries, Bruno Martins, Nayrema Maciel and Ricardo Carlos Schütz for helping during all animal experiment. Ana Paula G. Mortari is fellowship of "Coordenação de Aperfeiçoamento de Pessoal de Ensino Superior" (CAPES). Bruna P. Amaral, Pablo S.B. de Oliveira, Evelyn K. Dotto, Rudi Weiblen e Eduardo F. Flores hold fellowships from the "Conselho Nacional de Desenvolvimento Científico e Tecnológico" (CNPq). This study was financed in part by the "Coordenação de Aperfeiçoamento de Pessoal de Nível Superior - Brasil" (CAPES) - Finance Code 001.

Conflict of interest statement.- The authors have no conflicting interests.

\section{REFERENCES}

Allen G.P. \& Bryans J.T. 1986. Molecular epizootiology, pathogenesis, and prophylaxis of equine herpesvirus-1 infections. Prog. Vet. Microbiol. Immunol. 2:78-144.<PMid:2856183>

Allen G.P. \& Umphenour N. 2004. Equine coital exanthema. In: Coetzer J. \& Tustin R. (Eds), Infectious Diseases of Livestocks. Vol.2. Oxford University Press, Cape Town, p.868-874.

Bentz B.G., Maxwell L.K., Erkert R.S., Royer C.M., Davis M.S., MacAllister C.G. \& Clarke C.R. 2006. Pharmacokinetics of acyclovir after single intravenous and oral administration to adult horses. J. Vet. Intern. Med. 20(3):589-594. <http://dx.doi.org/10.1111/j.1939-1676.2006.tb02901.x><PMid:16734094>

Brown J.A., Mapes S., Ball B.A., Hodder A.D.J., Liu I.K.M. \& Pusterla N. 2007. Prevalence of equine herpesvirus-1 infection among Thoroughbreds residing on a farm on which the virus was endemic. J. Am. Vet. Med. Assoc. 231(4):577-580. <http://dx.doi.org/10.2460/javma.231.4.577> <PMid:17696859>

Carmichael L.E. \& Greene C.E. 2006. Canine herpesvirus infection, p.4753. In: Greene C.E. (Ed.), Infectious Diseases of the Dog and Cat. 3rd ed. Elsevier, Philadelphia.

Carmichael R.J., Whitfield C. \& Maxwell L.K. 2013. Pharmacokinetics of ganciclovir and valganciclovir in the adult horse. J. Vet. Pharmacol. Ther. 36(5):441-449. <http://dx.doi.org/10.1111/jvp.12029><PMid:23301502>

Coen D.M. \& Richman D.D. 2007. Antiviral agents, p.447-485. In: Knipe D.M. \& Howley P.M. (Eds), Fields Virology. 5th ed. Lippincott Williams and Wilkins, Philadelphia.

Crumpacker C.S. 1996. Ganciclovir. N. Engl. J. Med. 335(10):721-729. <http:// dx.doi.org/10.1056/NEJM199609053351007><PMid:8786764>

De Clercq E. 2008. Antivirals: current state of art. Future Virol. 3(4):393-405. <http://dx.doi.org/10.2217/17460794.3.4.393>

Dezengrini R., Silva S.C., Weiss M., Kreutz L.C., Weiblen R. \& Flores E.F. 2010. Activity of three antiviral drugs against bovine herpesviruses 1, 2 and 5 in cell culture. Pesq. Vet. Bras. 30(10):855-860. <http://dx.doi.org/10.1590/ S0100-736X2010001000008>

Egan J.J., Adamali H.I., Lok S.S., Stewart J.P. \& Woodcock A.A. 2011. Ganciclovir antiviral therapy in advanced idiopathic pulmonary fibrosis: an open pilot study. Pulm. Med. 2011:240805. <http://dx.doi.org/10.1155/2011/240805> <PMid:21660226>
Estell K.E., Dawson D.R., Magdesian K.G., Swain E., Laing S.T., Siso S., Mapes S. \& Pusterla N. 2015. Quantitative molecular viral loads in 7 horses with naturally occurring equine herpesvirus-1 infection. Equine Vet. J. 47(6):689693. <http://dx.doi.org/10.1111/evj.12351><PMid:25212737>

Garré B., Van der Meulen K., Nugent J., Neyts J., Croubels S., De Backer P. \& Nauwynck H. 2007a. In vitro susceptibility of six isolates of equine herpesvirus 1 to acyclovir, ganciclovir, cidofovir, adefovir, PMEDAP and foscarnet. Vet. Microbiol. 12(1/2):43-51. <http://dx.doi.org/10.1016/j. vetmic.2007.01.004><PMid:17276631>

Garré B., Shebany K., Gryspeerdt A., Baert K., van der Meulen K., Nauwynck H., Deprez P., De Backer P. \& Croubels S. 2007b. Pharmacokinetics of acyclovir after intravenous infusion of acyclovir and after oral administration of acyclovir and its prodrug valacyclovir in healthy adult horses. Antimicrob. Agents Chemother. 51(12):4308-4314. <http://dx.doi.org/10.1128/ AAC.00116-07><PMid:17846132>

Garré B. 2008. Pharmacokinetics and clinical efficacy of acyclovir in the treatment of equine herpesvirus type 1 infections. Master's Thesis, Faculty of Veterinary Medicine, Ghent University, Ghent, Belgium. 192p.

Gilkerson J.R, Whalley J.M., Drummer H.E. , Studdert M.J. \& Love D.N. 1999. Epidemiology of EHV-1 and EHV-4 in the mare and foal populations on a Hunter Valley stud farm: are mares the source of EHV-1 for unweaned foals. Vet. Microbiol. 68(1-2):27-34. <https://doi.org/10.1016/S03781135(99)00058-9>

Glorieux S., Vandekerckhove A.P., Goris N., Yang X.-Y., Steukers L., Van de Walle G.R., Croubels S., Neyts J. \& Nauwynck H.J. 2012. Evaluation of the antiviral activity of (1'S, 2'R)-9-[[1',2'-bis(hydroxymethyl)-cycloprop-1'-yl]methyl] $\mathrm{x}$ guanine (A-5021) against equine herpesvirus type 1 in cell monolayers and equine nasal mucosal explants. Antivir. Res. 93(2):234-238. <http:// dx.doi.org/10.1016/j.antiviral.2011.11.016><PMid:22178244>

Goodman L.B., Wimer C., Dubovi E.J., Gold C. \& Wagner B. 2012. Immunological correlates of vaccination and infection for equine herpesvirus 1. Clin. Vaccine Immunol. 19(2):235-241. <http://dx.doi.org/10.1128/CVI.05522$11><$ PMid:22205656>

Hedaya M.A. \& Sawchuk R.J. 1990. A sensitive and specific liquid-chromatographic assay for determination of ganciclovir in plasma and urine and its application to pharmacokinetic studies in the rabbit. Pharmacol. Res. 7(11):11131118. <http://dx.doi.org/10.1023/A:1015920023272><PMid:2293208>

ICTV 2018. International Committee on Taxonomy of Viruses. Available at <https://talk.ictvonline.org/taxonomy//> Accessed on Jan. 16, 2019.

Kanitz F.A., Cargnelutti J.F., Anziliero D., Gonçalves K.V., Masuda E.K., Weiblen R. \& Flores E.F. 2015. Respiratory and neurological disease in rabbits experimentally infected with equid herpesvirus 1. Microb. Pathog. 87:45-50. <http://dx.doi.org/10.1016/j.micpath.2015.07.007><PMid:26187161>

Kydd J.H., Slater J.D., Osterrieder K., Lunn D.P., Antczak D.F., Azab W., Balasuriya U., Barnett C., Brosnahan M., Cook C., Damiani A., Elton D., Frampton A., Gilkerson J., Goehring L., Horohov D., Maxwell L., Minke J., Morley P., Nauwynck H., Newton R., Perkins G., Pusterla N., Soboll-Hussey G., Traub-Dargatz J., Townsend H., Van de Walle G.R. \& Wagner B. 2012. Third international havemeyer workshop on equine herpesvirus type 1. Equine Vet. J. 44(5):513-517.<http://dx.doi.org/10.1111/j.2042-3306.2012.00604. $\mathrm{x}><$ PMid:22888774>

Lalezari J.P., Friedberg D.N., Bissett J., Giordano M.F., Hardy W.D., Drew W.L., Hubbard L.D., Buhles W.C., Stempien M.J., Georgiou P., Jung D.T. \& Robinson C.A. 2002. High dose oral ganciclovir treatment for cytomegalovirus retinitis. Roche Cooperative Oral Ganciclovir Study Group. J. Clin. Virol. 24(1/2):67-77. <http://dx.doi.org/10.1016/S1386-6532(01)00229-3> $<$ PMid:11744430>

Levinson W. 2016. Virologia básica, p.264-268. In: Ibid. (Ed.), Microbiologia Médica e Imunologia. 13a ed. AMGH, Porto Alegre.

Lunn D.P., Davis-Poynter N., Flaminio M.J., Horohov D.W., Osterrieder K., Pusterla N. \& Townsend H.G.G. 2009. Equine herpesvirus-1 consensus 
statement. J. Vet. Intern. Med. 23(3):450-461. <http://dx.doi. org/10.1111/j.1939-1676.2009.0304.x><PMid:19645832>

Ma G., Azab W. \& Osterrieder N. 2013. Equine herpesviruses type 1 (EHV-1) and 4 (EHV-4) - masters of co-evolution and a constant threat to equids and beyond. Vet. Microbiol.167(1/2):123-134. <http://dx.doi.org/10.1016/j. vetmic.2013.06.018><PMid:23890672>

Maggs D.J. \& Clarke H.E. 2004. In vitro efficacy of ganciclovir, cidofovir, penciclovir, foscarnet, idoxuridine and acyclovir against feline herpesvirus type-1. Am. J. Vet. Res. 65(4):399-403. <http://dx.doi.org/10.2460/ ajvr.2004.65.399><PMid:15077679>

Marley M.S., Givens M.D., Stringfellow D.A., Galik P.K. \& Riddell K.P. 2006. Effect of phosphonoformic acid in the development of bovine embryos in vitro. Vet. Ther. 7(2):156-166. <PMid:16871497>

Maxwell L.K. 2017. Antiherpetic drugs in equine medicine. Vet. Clin. N. Am., Equine Pract. 33(1):99-125.<http://dx.doi.org/10.1016/j.cveq.2016.12.002> $<$ PMid:28325183>

Maxwell L.K., Bentz B.G., Gilliam L.L., Ritchey J.W., Eberle R.W., Holbrook T.C., McFarlane D., Rezabek G.B., MacAllister G.C., Goad C.L. \& Allen G.P. 2008. Efficacy of valacyclovir against disease following EHV-1 challenge in aged mares. AAEP Proc. 54:198-199.

Meulen K.V.D., Garré B., Croubels S. \& Nauwynck H. 2006. In vitro comparison of antiviral drugs against feline herpesvirus 1. BMC Vet. Res. 2(1):1-7. <http://dx.doi.org/10.1186/1746-6148-2-1><PMid:16640781>

Mookerjee B.P. \& Vogelsang G. 1997. Human herpes virus-6 encephalitis after bone marrow transplantation: successful treatment with ganciclovir. Bone Marrow Transplant. 20(10):905-906.<http://dx.doi.org/10.1038/ sj.bmt.1700988><PMid:9404935>

Murray M.J., del Piero F., Jeffrey S.C., Davis M.S., Furr M.O., Dubovi E.J. \& Mayo J.A. 1998. Neonatal equine herpesvirus type 1 infection on a thoroughbred breeding farm. J. Vet. Intern. Med. 12(1):36-41. <http:// dx.doi.org/10.1111/j.1939-1676.1998.tb00494.x><PMid:9503358>

Oliveira A.L., Cargnelutti J.F., Mortari A.P.G., Flores E.F. \& Weiblen R. 2018. Atividade in vitro de seis drogas antivirais contra o alfaherpesvírus equino tipo 1. Ciência Rural 48(12):e20180085.

Patel J.R. \& Heldens J. 2005. Equine herpesviruses 1 (EHV-1) and 4 (EHV4)-epidemiology, disease and immunoprophylaxis: a brief review.
Vet. J. 170(1):14-23. <http://dx.doi.org/10.1016/j.tvjl.2004.04.018> <PMid:15993786>

Pusterla N. \& Hussey G.S. 2014. Equine Herpesvirus 1 Myeloencephalopathy. Vet. Clin. N. Am., Equine Pract. 30(3):489-506. <http://dx.doi.org/10.1016/j. cveq.2014.08.006> <PMid:25300635>

Pusterla N., Mapes S. \& Wilson W.D. 2010. Prevalence of equine herpesvirus type 1 in trigeminal ganglia and submandibular lymph nodes of equids examined postmortem. Vet. Rec. 167(10):376-379. <http://dx.doi. org/10.1136/vr.c3748> <PMid:20817899>

Razonable R.R. 2011. Antiviral drugs for viruses other than human immunodeficiency virus. Mayo Clin. Proc. 86(10):1009-1026. <http:// dx.doi.org/10.4065/mcp.2011.0309><PMid:21964179>

Schwers A., Pastoret P.P., Vindevogel H., Leroy P., Aguilar-Setien A. \& Godart M. 1980. Comparision of the effect of trisodium phosphonoformate on the mean plaque size of pseudorabies virus, infectious bovine rhinotraqueitis vírus and pigeon herpesvirus. J. Comp. Pathol. 90(4):625-633. <http:// dx.doi.org/10.1016/0021-9975(80)90111-5><PMid:6268670>

Shen W., Kim J.S., Mitchell S., Kish P., Kijek P. \& Hilfinger J. 2009. 5-O-D-VALYL ara $\mathrm{A}$, a potencial prodrug for improving oral biovailability of the antiviral agent vidarabine. Nat. Inst. Health 28(1):43-55. <PMid:19116869>

Thomasy S.M. \& Maggs D.J. 2016. A review of antiviral drugs and other compounds with activity against feline herpesvirus type 1 . Vet Ophthalmol. 19(Suppl.1):119-130. <http://dx.doi.org/10.1111/vop.12375> <PMid:27091747>

Vissani M.A., Thiry E., Dal Pozzo F. \& Barrandeguy M. 2015. Antiviral agents against equid alphaherpesviruses: current status and perspectives. Vet. J. 207:38-44.<http://dx.doi.org/10.1016/j.tvjl.2015.06.010><PMid:26654843>

Wang X., Wang L., Wu N., Ma X. \& Xu J. 2015. Clinical efficacy of oral ganciclovir for prophylaxis and treatment of recurrent herpes simplex keratitis. Chin. Med. J., England 128(1):46-50. <http://dx.doi.org/10.4103/03666999.147808><PMid:25563312>

Welch H.M., Bridges C.G., Lyon A.M., Griffiths L. \& Edington N. 1992. Latent equid herpesviruses-1 and 4-detection and distinction using the polymerase chain reaction and cocultivation from lymphoid-tissues. J. Gen. Virol. 73(Pt 2):261268. <http://dx.doi.org/10.1099/0022-1317-73-2-261><PMid:1347078>

Whitley R.J. \& Roizman B. 2001. Herpes simplex virus infections. Lancet. 357(9257):1513-1518. <http://dx.doi.org/10.1016/S0140-6736(00)046389 $><$ PMid:11377626> 